\title{
EFFECT OF PROCESS VARIABLES ON QUALITY IMPROVEMENT OF TGW PULPS OF EUCALYPTUS
}

\author{
Dalton Longue Júnior ${ }^{1 *}$, Jorge Luiz Colodette ${ }^{1}$, Gabriel de Castro Baião Brumano', \\ Edson Domingos da Silva ${ }^{1}$, Marcos Maurici Araújo Alves ${ }^{1}$
}

*Corresponding author: daltonufv@yahoo.com.br

\begin{abstract}
High-yield pulps are usually derived from pine wood on account of its anatomical configuration and technology used. Eucalyptus, on the other hand, is a fast-growing species, abundant in many parts of the world, and has thus emerged as an alternative source for many products in the pulp and paper industry. In this particular study, high-yield pulps of Eucalyptus grandis were used. In order to improve their properties, pulps were subjected to chemical treatments with different doses of sodium hydroxide prior to refining $(0,30,50$ and $70 \mathrm{~kg} / \mathrm{t})$, at $75^{\circ} \mathrm{C}$ temperature, $3 \%$ consistency, during 1 minute. The refining process was done in a Bauer disc refiner (Regmed) using various refining times $(0,5,10$ and 15 minutes). Results showed that refining with addition of $\mathrm{NaOH}$ did bring significant gains to the eucalyptus fibers regarding strength properties, the dose $50 \mathrm{~kg} / \mathrm{t}$ being found the most suitable. However, other variables associated with refining could also be modified to further improve the strength properties of eucalyptus pulps, including consistency and refining discs configuration.
\end{abstract}

Key words: High-yield pulp, sodium hydroxide, refining.

\section{EFEITO DAS VARIÁVEIS DE PROCESSO NA MELHORIA DA QUALIDADE DAS POLPAS TGW DE EUCALIPTO}

RESUMO: As polpas de alto rendimento são normalmente produzidas a partir de madeiras de pinus, pela anatomia de seus elementos e da tecnologia estabelecida. Entretanto, em razão do seu rápido crescimento e abundância em muitas partes do mundo, o eucalipto surgiu como uma fonte alternativa para muitos produtos no setor de celulose e papel. Para a realização desse trabalho, foram usadas polpas de alto rendimento de Eucalyptus grandis. Para melhorar suas propriedades, as polpas foram submetidas a tratamentos químicos com hidróxido de sódio em diferentes dosagens antes do refino $(0 ; 30 ; 50$ e $70 \mathrm{~kg} / \mathrm{t})$, nas seguintes condições (tempo: 1 minuto; temperatura: $75^{\circ} \mathrm{Ce} 3 \%$ de consistência). O refino foi realizado em um refinador de discos simples modelo Bauer da Regmed, sendo o tempo de refino variável (0; 5; 10 e 15 minutos). Pelos resultados, as fibras de eucalipto, quando refinadas e submetidas a tratamento químico com $\mathrm{NaOH}$, apresentam ganhos significativos em suas propriedades de resistência, sendo a carga de $50 \mathrm{~kg} / \mathrm{t}$ a mais indicada segundo esse estudo. Entretanto, outras variáveis associadas ao refino podem ser modificadas de modo a melhorar ainda mais as propriedades de resistência das polpas de eucalipto, como a consistência e configuração dos discos de refino.

Palavras-chave: Polpa de alto rendimento, hidróxido de sódio, refino.

\section{INTRODUCTION}

Eucalyptus pulps (hardwood) have aroused considerable interest in recent years due to their abundance in all parts of the world and to the high productivity and fiber characteristics of the genus which may be used in different applications by the paper industry, including in the mechanical pulping sector (XU; ZHOU, 2007). Mechanical pulping processes convert wood into high-yield pulps characterized by high bulk, high opacity and low production cost in comparison with chemical processes (HOLIK, 2006; LINDHOLM; KURDIN, 1999).

A major drawback of mechanical pulping is the high energy consumption involved in the process and the inferior strength properties of the resulting pulps (HOLIK, 2006; LINDHOLM; KURDIN, 1999). The cost entailed in such process could exceed $35 \%$ of the total pulp manufacturing cost, depending on the local conditions (HUHTANEN et al., 2004). For this reason, the wood material and technological processes being used should be carefully evaluated for quality.

With shorter, thinner-walled fibers, hardwoods tend to be more severely damaged during the mechanical pulping process, hence their inferior strength properties. thus, these short-fiber hardwoods have potential for production of mechanical pulp provided that certain changes are made to the relevant processes.

The refining process brings considerable changes to the pulp properties and thus has a significant effect on the formation of paper. Suitable refining entails internal and external fibrillation, fiber shortening and release of fines so as to improve the properties of resulting products.

\footnotetext{
${ }^{1}$ Universidade Federal de Viçosa - Viçosa, Minas Gerais, Brazil
} 
Some authors report that the fiber shortening effect exerted by refining does improve paper formation by reducing the number of lumps and consequently leading to a reduced occurrence of flocks and reduced propensity to flocculation (KEREKES; SCHELL, 1992). Therefore, where refining follows the specific conditions imposed for a given wood group, it does potentiate the development of strength properties.

To improve strength properties of mechanical pulps of eucalyptus while reducing energy consumption, fibers can be subjected to chemical stages that will facilitate the refining actions (LINDHOLM; KURDIN, 1999; XU; ZHOU, 2005). Many chemicals can be used in that stage, noting that, in practice, sodium sulfite is the dominant chemical reagent in processes with coniferous woods (softwood) whereas sodium hydroxide and/or sodium sulfite are the most common chemical reagents in processes with deciduous woods (hardwood) (LINDHOLM; KURDIN, 1999).

Total or partial replacement of pine wood (softwood) by eucalyptus wood (hardwood) in a mechanical pulping mill is thus possible, provided that the variables involved in the process are reassessed and provided that chemical treatments are performed, including addition of sodium hydroxide to TGW pulps prior to refining (XU; SABOURIN, 1999). Such changes are intended to improve fiber quality and consequently improve the properties of the resulting pulp while reducing energy consumption.

The objective of this study was to evaluate the effect of chemical treatments with different doses of sodium hydroxide, in association with refining times, on the quality of TGW pulps of Eucalyptus grandis in an attempt to improve their physico-mechanical properties, in particular the tensile index.

\section{MATERIAL AND METHODS}

The material used was industrial TGW pulps of Eucalyptus grandis as collected from the industrial plant of a mechanical pulping company. The pulps were dewatered and kept in cold storage to prevent changes to their chemical composition.

\subsection{Preliminary tests}

Preliminary tests were performed to decide on pulp refining conditions to be used. Tests included two reaction times with $\mathrm{NaOH}$ ( 1 and 5 minutes), two reaction temperatures $\left(75\right.$ and $95^{\circ} \mathrm{C}$ ), and three distances between discs $(0.50,0.38$ and $0.25 \mathrm{~mm})$. Selection of the best conditions was based on the degree of drainage resistance and on strength properties (burst, tear and tensile index), as illustrated in Figure 1.

\subsection{Chemical treatment with sodium hydroxide}

A total of 30 liters of fibrous suspension was created by using $900 \mathrm{~g}$ of TGW pulp of eucalyptus at $3 \%$ consistency. The suspension was manually stirred in a plastic container for the duration time of the $\mathrm{NaOH}$ reaction. The conditions used in the chemical trial were 1 minute of reaction time, $75^{\circ} \mathrm{C}$ of reaction temperature and $0.25 \mathrm{~mm}$ of gap between discs. Control variables included $\mathrm{NaOH}$ doses $(0,30,50$ and $70 \mathrm{~kg} / \mathrm{t})$ and refining times $(0,5,10$ and 15 minutes), according to the experimental design shown in Figure 1.

\subsection{Pulp refining}

Once subjected to the chemical treatment, the pulps were taken to a Bauer single-disc laboratory refiner (Model MD3000 - Regmed). In all treatments, the refining discs were $20 \mathrm{~cm}$ in diameter and specific for use with shortfiber woods, having refining elements $3-\mathrm{mm}$ wide and separated by $3-\mathrm{mm}$ gaps, all aligned at a $45^{\circ}$ angle to the central axis. The pulps were washed with water to remove excess $\mathrm{NaOH}$ and then centrifuged for a more thorough cleansing of the material.

The gap set between discs was $0.25 \mathrm{~mm}$ in such way as to allow a wide variation in the Schopper-Riegler

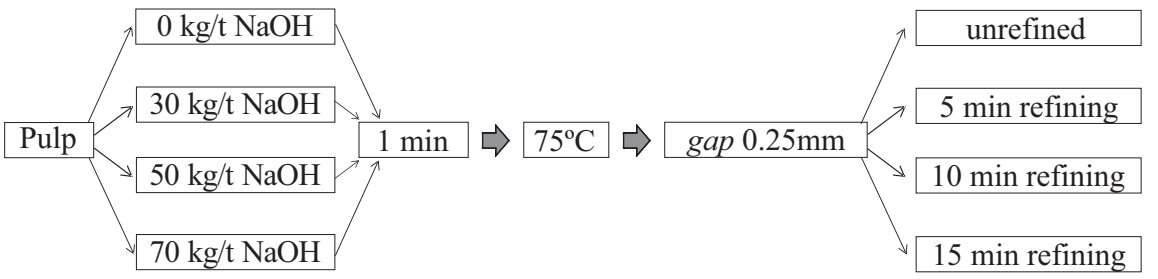

Figure 1 - Experimental design.

Figura 1 - Delineamento experimental.

Cerne, Lavras, v. 19, n. 4, p. 567-574, out./dez. 2013 
value and greater variability in other properties. Screening was done in a Voith laboratory screen device equipped with a screenplate with 0.20 -mm perforations. The pulp was dewatered and centrifuged to a $30 \%$ consistency. Handsheets with a grammage of around $200 \mathrm{~g} / \mathrm{m}^{2}$ were then made for all testing procedures. All treatments were performed in duplicate.

\subsection{Technological analysis of pulps associated with fiber morphology}

The technological characteristics of pulps associated with fiber morphology under assessment in this study were number of fiber elements per gram and fines content. For the analysis, a GALAI CIS- 100 particle analyzer was used and results were processed using Wshape software application. For determination of fines content, all elements equal to or less than $0.07 \mathrm{~mm}$ in size were considered. All analyzes were performed in duplicate.

\subsection{Optical and physico-mechanical tests}

Following the treatments, the handsheets formed were subjected to the following optical and physicomechanical tests: Brightness (Tappi T452-om 98), Manual handsheet forming method (ISO-5269-1), Tensile index (ISO 1924/2:94), Thickness (ISO 534:05), Grammage (ISO 536:95), Shopper-Riegler value (ISO 5267/1), Elongation (ISO1924/2:94), Breaking length (ISO1924/2:94), Stiffness (Tappi T489-om 99), Tear Index (ISO 1974:90), Bulk (ISO 534:05), Scott Bond (Tappi T541-om 99), and Ply bond strength (Tappi T541-om 05). The Brightness and Schopper-Riegler tests were performed in duplicate whereas the other tests had 5 replicates.

\subsection{Statistical analysis}

The experiment was laid out in a completely randomized design (CRD) using a factorial arrangement with two factors $(\mathrm{NaOH}$ doses and refining times). For analysis of the physico-mechanical and optical results, software applications Statistica 9.0 and Microsoft Office Excel 2007 were used. To study the effect of $\mathrm{NaOH}$ doses on pulp properties, four quadratic-linear equations were modeled for each property $(\mathrm{Y})$ as a function of refining time $(\mathrm{X})$ between 0 and 15 minutes. Each equation represented one $\mathrm{NaOH}$ dose being used in this trial ( 0 to 70 $\mathrm{kg} / \mathrm{dry}$ ton). The four equations were statistically analyzed by regression analysis and compared by the F-test, using the model identity test and adopting a significance level of $5 \%$ probability, according to the methodology suggested by Regazzi (1993) for linear models.

All equations were initially tested assuming equality between them $\left(\mathrm{H}_{0}=\right.$ null hypothesis). If $\mathrm{H}_{0}$ was accepted, a common equation would be used to represent the behavior of the property of interest (Y) as a function of each refining time (X). If the null hypothesis was rejected, comparisons would be made of the equations in pairs to identify which $\mathrm{NaOH}$ doses affected the pulp properties $(\mathrm{Y})$ as a function of refining. Effects of refining or interactions between $\mathrm{NaOH}$ doses $\mathrm{x}$ refining times were not discussed in this study since it is common knowledge that refining does improve pulp properties and noting that only $\mathrm{NaOH}$ addition to the process is new to the study.

To illustrate the effect of alkali treatment on pulp properties under different refining times, a surface plot was created using the software application Statistica.

\section{RESULTS AND DISCUSSION}

\subsection{Technological analysis of pulps associated with fiber morphology}

Paper properties are subject to the influence of the morphological characteristics of the fibers. Such characteristics are determining factors in the flexibility and conformability of the fibers, both playing a critical part in the interfiber bonding capability thought to be essential for suitable formation and strength of paper (SILVA, 2002).

Refining increases the intertwining of fibrous material by promoting both internal and external fibrillation, cutting fibers and releasing fines (ALMEIDA, 1988). The combination of these effects leads to increased intra- and interfiber bonding and culminates with an overall increase in strength properties. However, if applied overly, refining has deleterious effects on such properties as it will make the material much too small by excessively cutting the fibers. Following the same line of reasoning, a chemical treatment with $\mathrm{NaOH}$ can be used to promote fiber swelling and facilitate the refining action, that way contributing to increase the strength properties of the pulp.

Since refining causes cuts to the fibers, which is undesirable though unavoidable, the number of fiber elements per gram (Figure 2a) and the fines content (Figure $2 b)$ were found to be higher in refined pulps. Although the number of fiber elements per gram increased with increasing $\mathrm{NaOH}$ doses in the case of the refined pulps, $\mathrm{NaOH}$ addition did not favor formation of fines inasmuch as the fines content in refined pulps remained virtually constant for all $\mathrm{NaOH}$ doses applied.

Refining causes cuttings to the fibers, producing a

Cerne, Lavras, v. 19, n. 4, p. 567-574, out./dez. 2013 

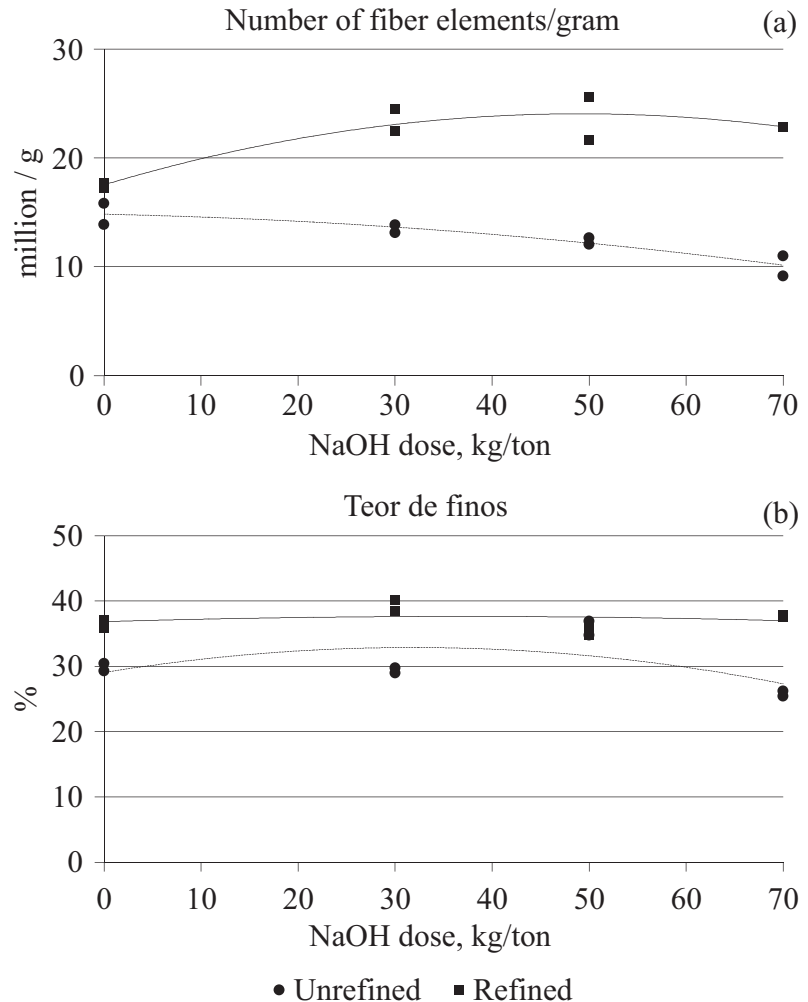

Figure 2 - Effect of alkali treatments and refining times on technological characteristics associated with fiber morphology.

Figura 2 - Efeito dos tratamentos alcalinos e do tempo de refino nas características tecnológicas associadas à morfologia de fibras.

large quantity of very tiny material $(<0.07 \mathrm{~mm})$. Because of their size, fines have a high specific surface area and that helps promote interfiber bonding. The contribution of fines, even if in small quantities, denotes the important role of this fraction in connection with the flexibility and collapsibility of fibers (SILVA, 2002).

\subsection{Optical and physico-mechanical properties of pulps}

Refining degree can be indirectly indicated by the drainage resistance of a fiber suspension and, in Brazil, the term Schopper-Riegler degree ( $\left.{ }^{\circ} \mathrm{SR}\right)$ is commonly used to address that, noting that the greater the water retention by the suspension, the higher the degree. In the trials run in this study, the Schopper-Rielger degree ranged from 15.5 to $51.0^{\circ} \mathrm{SR}$ (Figure 3a), indicating that refining and chemical treatment significantly increased the drainage resistance. As shown in Figure 2b, since the fines content remained constant in the refined pulps, the increase in drainage resistance can be attributed to more intertwining of the fibers.

Tensile strength is a measure of the force required to rupture a paper strip when its width and the load speed are standardized. The tensile index is determined by dividing the maximum stress supported by the test piece before rupture by its grammage. The tensile index increased significantly as trials progressed, ranging from 1.9 to 14.3 $\mathrm{kN} . \mathrm{m} / \mathrm{g}$. This gain is thought to be significant, since the reference value for industrial TGW pulp of pine wood is close to $7.2 \mathrm{kN} . \mathrm{m} / \mathrm{g}$.

tear index by definition is the force required by a pendulum to tear multiple plies after a tear of specified length has been started on the samples. The tear index is determined by dividing the average force required to tear one ply by its grammage. The tear index had a good development as trials progressed, with values ranging from 0.9 to $3.4 \mathrm{mN} . \mathrm{m}^{2} / \mathrm{g}$. It was nonetheless less expressive with higher $\mathrm{NaOH}$ doses.

Breaking length is the length that a strip with a given grammage and width can be suspended immediately before it would break under its own weight. In this work, breaking length ranged from 0.2 to $1.4 \mathrm{~km}$, proving adequate if compared with the reference value for industrial TGW pulp of pine wood, around $0.7 \mathrm{~km}$.

Increasing refining time was found to promote increases in Schopper-Riegler degree, tensile index, tear index and breaking length. Addition of $\mathrm{NaOH}$ also improved the above properties, whereby the greater the amount of $\mathrm{NaOH}$ added, the greater the increases, particularly at longer refining times, with the exception of Schopper-Riegler degree and tear index, whose curves did not show statistical differences with increasing $\mathrm{NaOH}$ doses (Table 1).

Brightness is defined as the reflectance factor of blue light at a wavelength of $457 \mathrm{~nm}$. Brightness was found to be negatively affected by the treatments and ranged between 55.2 and $35.3 \%$ ISO. Elongation is determined concurrently with tensile strength by using a dynamometer attachment. It is given as percentage and indicates how much a paper sample deforms before its complete rupture. This property ranged from 0.5 to $1.2 \%$, with improvement as trials progressed. The reference value of elongation for industrial TGW pulps of pine wood is around $1.0 \%$.

Being an optical property, brightness was found to be more influenced by $\mathrm{NaOH}$ concentration than by refining time. In all refining times studied, brightness decreased with increasing $\mathrm{NaOH}$ doses (Figure 3e). Pulp

Cerne, Lavras, v. 19, n. 4, p. 567-574, out./dez. 2013 
(a)

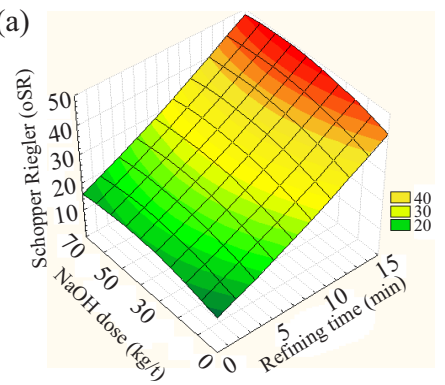

(d)

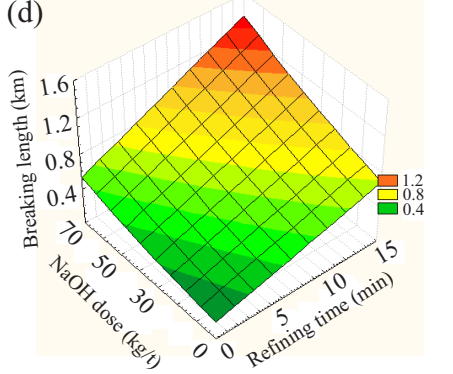

(g)

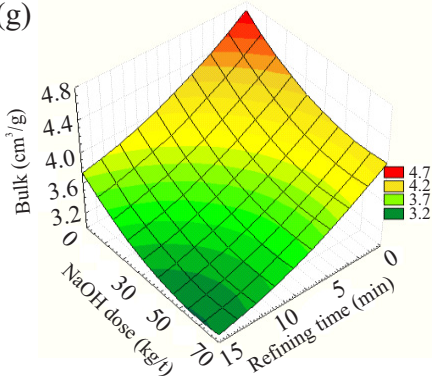

(b)

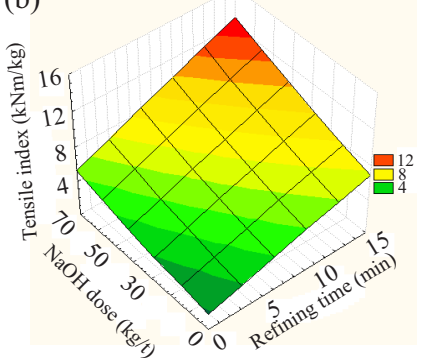

(e)

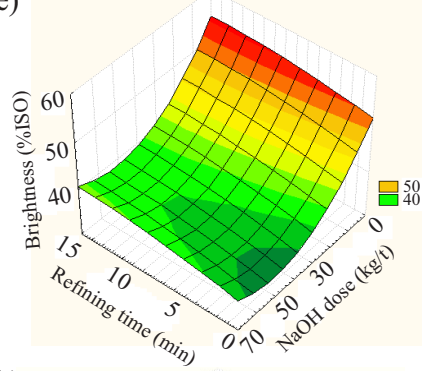

(h)
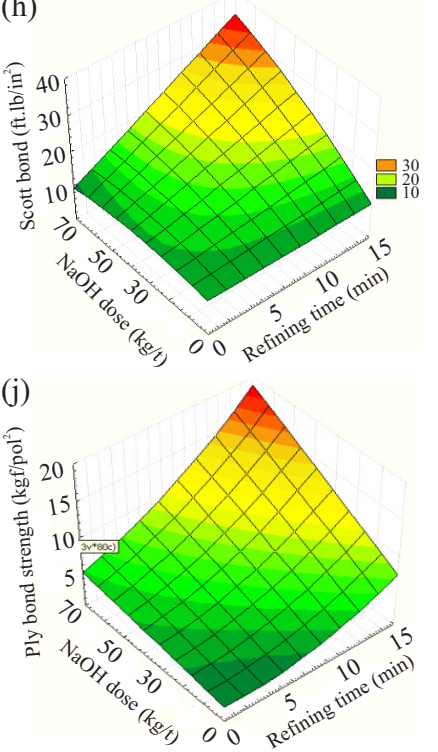

(c)

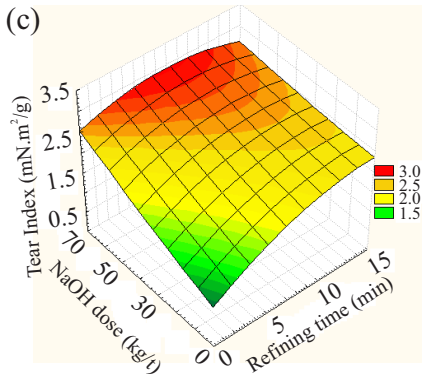

(i)

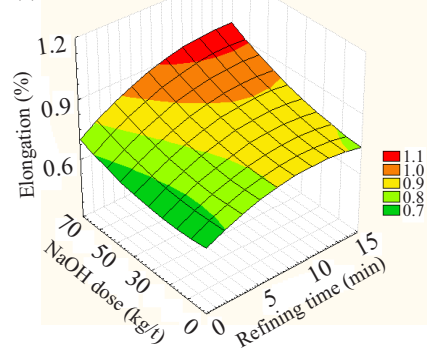

(1)

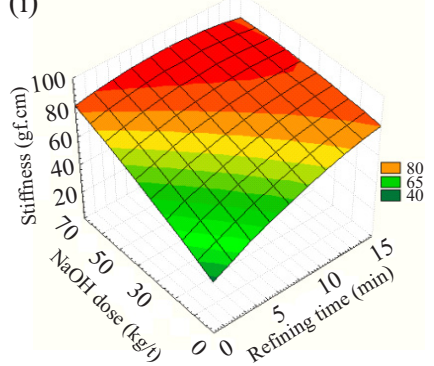

Figure 3 - Effect of refining time and $\mathrm{NaOH}$ dose on the development of the properties of interest.

Figura 3 - Efeito do tempo de refino e da carga de $\mathrm{NaOH}$ no desenvolvimento das propriedades avaliadas nesse estudo.

tends to become darker when subjected to thermochemical treatment with $\mathrm{NaOH}$ on account of the chemical changes undergone by its chemical components, which make bleaching at higher levels of brightness more difficult to achieve, especially when hardwoods are used (XU, 1997). Lignins found in hardwood (syringyl lignin) are more reactive and oxidize faster than guaiacyl lignins, present in less quantity. And absence of an extraction stage to remove such oxidized lignins confers a darker shade on pulps treated with sodium hydroxide.

Elongation was found to increase with more refining time, particularly when pulp was treated with higher $\mathrm{NaOH}$ doses (Figure 3f). This property followed the same pattern as tensile index, indicating enhanced interfiber bonding and improved strength properties.

Bulk is obtained by dividing paper thickness by

Cerne, Lavras, v. 19, n. 4, p. 567-574, out./dez. 2013 
Table 1 - Summary of the model identity test for all properties of interest.

Tabela 1 - Resumo do teste de identidade de modelos para todas as propriedades avaliadas nesse estudo.

\begin{tabular}{|c|c|c|c|c|c|c|c|c|c|}
\hline \multicolumn{5}{|c|}{ Schopper-Riegler degree } & \multicolumn{5}{|c|}{ Tensile index } \\
\hline Eq. $1 *$ & Eq. $2 *$ & Result & F calc & F tab & Eq. $1 *$ & Eq. $2 *$ & Result & F calc & $\mathrm{F}$ tab \\
\hline 0 & 30 & Different & 29.2 & 3.48 & 0 & 30 & Different & 34,3 & 2,65 \\
\hline 0 & 50 & Different & 11.7 & 3.48 & 0 & 50 & Different & 122.2 & 2.65 \\
\hline 0 & 70 & Different & 28.2 & 3.48 & 0 & 70 & Different & 53.3 & 2.65 \\
\hline 30 & $50 * *$ & Similar & 0.3 & 3.48 & 30 & 50 & Different & 21.8 & 2.65 \\
\hline 30 & 70 & Different & 5.6 & 3.48 & 30 & 70 & Different & 20.9 & 2.65 \\
\hline 50 & $70 * *$ & Similar & 1.4 & 3.48 & 50 & 70 & Different & 4.2 & 2.65 \\
\hline \multicolumn{5}{|c|}{ Tear index } & \multicolumn{5}{|c|}{ Breaking length } \\
\hline 0 & 30 & Different & 5.2 & 2.65 & 0 & 30 & Different & 34.0 & 2.65 \\
\hline 0 & 50 & Different & 9.6 & 2.65 & 0 & 50 & Different & 122.2 & 2.65 \\
\hline 0 & 70 & Different & 39.4 & 2.65 & 0 & 70 & Different & 110.5 & 2.65 \\
\hline 30 & $50 * *$ & Similar & 2.2 & 2.65 & 30 & 50 & Different & 21.5 & 2.65 \\
\hline 30 & 70 & Different & 9.7 & 2.65 & 30 & 70 & Different & 41.4 & 2.65 \\
\hline 50 & $70 * *$ & Similar & 1.6 & 2.65 & 50 & 70 & Different & 10.2 & 2.65 \\
\hline \multicolumn{5}{|c|}{ Brightness } & \multicolumn{5}{|c|}{ Elongation } \\
\hline 0 & 30 & Different & 6548 & 3.48 & 0 & 30 & Different & 3.1 & 2.65 \\
\hline 0 & 50 & Different & 2945 & 3.48 & 0 & 50 & Different & 6.2 & 2.65 \\
\hline 0 & 70 & Different & 5657 & 3.48 & 0 & 70 & Different & 7.8 & 2.65 \\
\hline 30 & 50 & Different & 8.8 & 3.48 & 30 & $50 * *$ & Similar & 0.3 & 2.65 \\
\hline 30 & 70 & Different & 69 & 3.48 & 30 & 70 & Different & 3.5 & 2.65 \\
\hline 50 & 70 & Different & 7.4 & 3.48 & 50 & 70 & Different & 4.5 & 2.65 \\
\hline \multicolumn{5}{|c|}{ Bulk } & \multicolumn{5}{|c|}{ Scott Bond } \\
\hline 0 & 30 & Different & 55.0 & 2.65 & 0 & 30 & Different & 14.8 & 2.65 \\
\hline 0 & 50 & Different & 222.6 & 2.65 & 0 & 50 & Different & 56.7 & 2.65 \\
\hline 0 & 70 & Different & 44.3 & 2.65 & 0 & 70 & Different & 34.9 & 2.65 \\
\hline 30 & $50 * *$ & Different & 20.5 & 2.65 & 30 & 50 & Different & 27.0 & 2.65 \\
\hline 30 & 70 & Different & 3.1 & 2.65 & 30 & 70 & Different & 12.1 & 2.65 \\
\hline 50 & $70 * *$ & Similar & 1.8 & 2.65 & 50 & $70 * *$ & Different & 12.0 & 2.65 \\
\hline \multicolumn{5}{|c|}{ Stiffness } & \multicolumn{5}{|c|}{ Ply bond strength } \\
\hline 0 & 30 & Different & 14.5 & 2.65 & 0 & 30 & Different & 57.0 & 3.48 \\
\hline 0 & 50 & Different & 14.2 & 2.65 & 0 & 50 & Different & 123.7 & 3.48 \\
\hline 0 & 70 & Different & 32.4 & 2.65 & 0 & 70 & Different & 82.7 & 3.48 \\
\hline 30 & $50 * *$ & Similar & 0.6 & 2.65 & 30 & 50 & Different & 15.9 & 3.48 \\
\hline 30 & 70 & Different & 3.4 & 2.65 & 30 & 70 & Different & 21.3 & 3.48 \\
\hline 50 & $70 * *$ & Similar & 0.8 & 2.65 & 50 & $70 * *$ & Similar & 3.2 & 3.48 \\
\hline
\end{tabular}

*Eq.1 and Eq.2: Comparison of equations, in pairs, for different $\mathrm{NaOH}$ doses.

**Common equation in replacement of Equations 1 and 2.

Cerne, Lavras, v. 19, n. 4, p. 567-574, out./dez. 2013 
its grammage. Structural characteristics of fibers also influence the determination of this property, it being associated with consolidation capability of the paper structure. Bulk is thought to be one of the most important properties of mechanical pulps, influencing both the physical and optical properties of cellulose pulps and affected by myriad factors which include degree of interfiber bonding, presence of nonfibrous materials filling voids, among other things. Results showed that Bulk decreased from 4.8 to $2.8 \mathrm{~cm}^{3} / \mathrm{g}$ as treatments progressed. This reduction should be carefully monitored because specific volume is a very important property of high-yield pulps. An industrial TGW pulp of pine wood has values of around $3.4 \mathrm{~cm}^{3} / \mathrm{g}$.

The Scott Bond test, also known as Z-directional force, is the capability of a product to withstand separation when tension is applied in the thickness direction of paper, that is, in the Z-direction of the ply. Unlike specific volume, the Scott Bond of pulps increased from 10 to $40 \mathrm{ft} . \mathrm{lb} /$ in $^{2}$ with increasing refining time associated with $\mathrm{NaOH}$ addition. The reference value for this property using industrial TGW pulp of pine wood is $20 \mathrm{ft} .1 \mathrm{~b} / \mathrm{in}^{2}$.

With intensified refining, specific volume decreased, particularly when higher $\mathrm{NaOH}$ doses were applied (Figure $3 \mathrm{~g}$ ). This reduction in specific volume is not very desirable, thus it is unavoidable whenever refining is intended to improve strength properties of pulps, since the degree of fiber collapsibility increases. In contrast with bulk b, Scott Bond increased significantly with increasing refining time, particularly when higher $\mathrm{NaOH}$ doses were applied (Figure $3 \mathrm{~h}$ ). Regarding these two properties, much desired for mechanical pulps, an intermediate pulp with reasonable specific volume and a significant Scott Bond value would be ideal.

A model identity test showed that all equations, compared in pairs for these four properties, were statistically different, indicating that the treatments proposed were effective (Table 1).

Stiffness is defined as the capability of a test piece to withstand bending from its own weight. Stiffer fibers help increase the specific volume of papers because of their limited conformation capability (HOWARD; BICHARD, 1992). Pulp stiffness was found to increase from 36 to 99 gf.cm as treatments progressed, 69 gf.cm being the reference value for industrial TGW pulp of pine wood.

As regards delamination, it is caused by insufficient adhesion between adjacent plies of a material, and in the case of wood pulp it means insufficient interaction between fibers. As treatments were applied, ply bond strength ranged from 1.8 to $19 \mathrm{kgf} / \mathrm{pol}^{2}$. The reference value for industrial TGW pulp of pine wood is around $5.4 \mathrm{kgf} / \mathrm{pol}^{2}$. Increasing refining times helped increase both above mentioned properties. For ply bond strength, a greater increment was achieved when higher $\mathrm{NaOH}$ doses were used, whereas for stiffness the refining time was not significant when higher $\mathrm{NaOH}$ doses were used (Figures $3 \mathrm{i}$ and $3 \mathrm{j}$ ). Table 1 shows the negligible effect of higher $\mathrm{NaOH}$ doses on stiffness.

\section{CONCLUSIONS}

Eucalyptus short fibers, once refined and subjected to chemical treatment with $\mathrm{NaOH}$, were found to real significant gains in their strength properties, even when compared with industrial TGW pulps of pine wood. Brightness and bulk, however, were significantly affected in a negative way by such treatments.

Other variables associated with refining can be modified to further improve strength properties of eucalyptus pulps, including consistency and refining disc configuration for hardwoods.

Intermediate $\mathrm{NaOH}$ doses should be applied, noting that, for some properties, $\mathrm{NaOH}$ doses above $50 \mathrm{~kg} / \mathrm{t} \mathrm{had}$ no significant effects.

\section{REFERENCES}

ALMEIDA, M. L. O. d'. Celulose e papel: tecnologia de fabricação do papel. São Paulo: IPT, 1988. 403 p.

HOLIK, H. Handbook of paper and board. Ravensburg: Wiley-VCH, 2006. 505 p.

HOWARD, R. C.; BICHARD, W. The basis effects of recycling on paper properties. Journal of Pulp and Paper Science, Montreal, v. 4, n. 18, p. 151-159, 1992.

HUHTANEN, J. P.; KARVINEN, R.; VIKMAN, K.; VUORIO, P. Theoretical background of new energy saving refiner segments design. In: ENERGY AND CARBON MANAGEMENT CONFERENCE, 1., 2004, Helsinki. Proceedings... Helsinki: ECM, 2004. p. 111-117.

KEREKES, R. J.; SCHELL, C. J. Characterization of fiber flocculation regimes by a crowding factor. Journal of Pulp and Paper Science, Montreal, v. 1, n. 18, p. 32-38, 1992.

Cerne, Lavras, v. 19, n. 4, p. 567-574, out./dez. 2013 
LINDHOLM, C. A.; KURDIN, J. A. Chemimechanical pulping. In: SUNDHOLM, J. (Ed.). Mechanical pulping. Helsinki: FAPET, 1999. p. 223-249.

REGAZZI, A. Teste para identificar a identidade de modelos de regressão e igualdade de alguns parâmetros num modelo polinomial ortogonal. Revista Ceres, Viçosa, v. 40, n. 228, p. 176-195, 1993.

SILVA, R. P. Utilização de vibrações ultra-sônicas para o refino de celulose kraft de eucalipto. 2002. 88 p. Dissertação (Mestrado em Ciência Florestal) - Universidade Federal de Viçosa, Viçosa, 2002.

XU, E. C. Chemical treatment in mechanical pulping: part 1, South American Eucalyptus: process and properties.
In: TAPPI PULPING CONFERENCE, 1., 1997, San Francisco. Proceedings... San Francisco: TAPPI, 1997. p. 985-998.

XU, E. C.; SABOURIN, E. J. Evaluation of APMP and BCTMP for market pulps from South American eucalyptus. Tappi Journal, Atlanta, v. 12, n. 82, p. 75-82, 1999.

XU, E. C.; ZHOU, Y. Synergistic effects between chemical mechanical pulps and chemical pulps from hardwoods. Tappi Journal, Atlanta, v. 6, n. 11, p. 4-9, 2007.

XU, E. C.; ZHOU, Y. Synergistic effects between P-RC APMP and bleached kraft pulps from Canadian Aspen. Appita Journal, Quebec, v. 58, n. 6, p. 481-483, 2005.

Received: September 8, 2011; accepted: May 24, 2013.

Cerne, Lavras, v. 19, n. 4, p. 567-574, out./dez. 2013 